\title{
TREATMENT OF NON-GONOCOCCAL URETHRITIS WITH
}

\section{DEMETHYLCHLORTETRACYCLINE ("LEDERMYCIN")*†}

\author{
BY \\ G. W. CSONKA AND N. ROSEDALE \\ Central Middlesex Hospital and St. Mary's Hospital, London
}

It has been shown by several investigators that the tetracycline group comprise the most effective antibiotic therapy in non-gonococcal urethritis (NGU), although no drug or combination of drugs so far tried has been entirely successful in this condition (Harkness, 1953; Doyle, Gill, and Laird, 1957; Willcox, 1957; Leach, 1959; Csonka, 1959; and many others).

Demethylchlortetracycline (DMCT) belongs to the family of demethyltetracycline which was characterized by McCormick, Sjólander, Hirsch, Jensen, and Doerschuk (1957). Important practical advantages are claimed over other antibiotics (Kunin and Finland, 1958, 1959; Finland and Garrod, 1960; Editorial, Brit. med. J., 1959). Its activity against many bacteria exceeds that of chlortetracycline by a factor of two and the antibiotic is exceedingly stable. It is much more slowly excreted than other tetracyclines and, therefore, sustains an adequate level in the blood for a longer period. This has the advantage that only two daily doses are required and, as it has greater therapeutic activity than tetracycline, a smaller dosage should achieve the desired effect with a corresponding saving in cost.

Although its antibacterial spectrum is said to be similar to that of chlortetracycline, this aspect has not yet been fully explored. It was noted that DMCT proved effective in vitro against more strains of Gram-negative bacteria commonly found in urogenital infections than did other tetracyclines (Vineyard, Hogan, and Sanford, 1959-60).

From these reports, DMCT appears to be the most promising tetracycline so far available but its value can only be assessed by clinical trials. We have evaluated DMCT in NGU at two different dosage

* "Ledermycin" is the trade mark of Lederle Laboratories.

† Received for publication February 6, 1962. levels and have compared it with "Achromycin V" (tetracycline buffered with citric acid or sodium metaphosphate) as a representative of the tetracycline group in the dosage in current use at our two clinics.

\section{Material and Methods}

150 consecutive male patients with NGU attending the Venereal Diseases departments at the Central Middlesex Hospital and St. Mary's Hospital, Paddington, were allotted to one of three treatment groups by the use of random sampling numbers. Gonococci and Trichomonas vaginalis were excluded by microscopical examination before treatment was started. The dosage schemes were as follows:

(1) Fifty patients were given $600 \mathrm{mg}$. DMCT daily (in two divided doses) for 3 days, a total of $1.8 \mathrm{~g}$.

(2) Fifty patients received the same daily dosage of DMCT for 6 days, a total of $3.6 \mathrm{~g}$.

(3) Fifty patients were given $1 \mathrm{~g}$. Achromycin $\mathrm{V}$ daily (in four divided doses) for 4 days, a total of $4 \mathrm{~g}$.

The patients were examined a week after the start of treatment and then at weekly intervals for the first month and at fortnightly intervals for the second month. The response was considered satisfactory if there were no symptoms and no urethral discharge and the urine was clear in the two-glass test. In cases of persistent or recurrent urethritis, a further search for Trichomonas vaginalis was made, and, where indicated, urethral stricture was excluded. Owing to the uncertainty in differentiating between relapse and re-infection, especially during the early stages, after an attack of NGU, all recurrences during the follow-up period of 2 months were considered to be treatment failures.

\section{Results}

One week after the start of treatment there was a favourable response in 89.8 per cent. of the patients on 3 days of DMCT, 92.9 per cent. of those on 
6 days of DMCT, and $90 \cdot 3$ per cent. of those on Achromycin V (Table I).

After 3 weeks the response was satisfactory in 86.8 per cent. of the patients on 3 days of DMCT, 80 per cent. of those on 6 days of DMCT and 73.8 per cent. of those on Achromycin: however, the default rate by this time had become too high to allow a strict statistical comparison and our conclusions, therefore, are based on the early results. The majority of treatment failures occurred within 3 weeks of starting therapy. In an attempt to find common factors in cases not responding to treatment, the history of all patients was scrutinized for past episodes of NGU and its response to treatment. The treatment given for the past attacks was varied, including terramycin, chloramphenicol, various sulphonamides, and streptomycin alone or in combination with sulphadiazine. It did not include any of the antibiotics given for the present attack. Some of the patients had more than one attack in the past. The same criteria in assessing success or failure were applied for the past as for the present attacks. This was made easier by the fact that most of the past attacks had been treated by the authors. The findings are correlated with the present treatment results in Table II. 26. 4 per cent. of patients who responded to the present treatment schedules had had previous attacks of NGU and of these $24 \cdot 1$ per cent. were treatment failures. 56.5 per cent. of present treatment failures had had previous attacks of NGU with a failure rate of 53.8 per cent. In this series, therefore, the patients who failed to respond to treatment were those with a higher incidence of past NGU than those who responded, and there was also a significantly higher therapeutic failure rate in past episodes of NGU in patients who failed with the present treatment.

The duration of symptoms before treatment might have a bearing on the response to therapy but, as can be seen from Table III, this period was evenly distributed between the groups of patients. Age, social class, race, and marital status were similar in patients who responded to treatment and those who did not. Investigation of the sexual contact was contemplated but had to be abandoned because more than three-quarters of the total number failed to attend.

TABLE III

DURATION OF SYMPTOMS BEFORE TREATMENT

\begin{tabular}{|c|c|c|c|c|c|c|c|}
\hline \multirow{2}{*}{\multicolumn{2}{|c|}{ Treatment Group }} & \multicolumn{6}{|c|}{ Duration of Symptoms (days) } \\
\hline & & $0-3$ & $4-6$ & $7-9$ & $10-12$ & $13-21$ & $22+$ \\
\hline \multicolumn{2}{|c|}{$\begin{array}{l}\text { DMCT 3-day Schedule } \\
\text { DMCT 6-day Schedule } \\
\text { Achromycin V }\end{array}$} & $\begin{array}{l}20 \\
23 \\
18\end{array}$ & $\begin{array}{l}12 \\
15 \\
16\end{array}$ & $\begin{array}{l}7 \\
3 \\
6\end{array}$ & $\begin{array}{l}3 \\
0 \\
4\end{array}$ & $\begin{array}{l}7 \\
7 \\
4\end{array}$ & $\begin{array}{l}1 \\
2 \\
2\end{array}$ \\
\hline Totals & $\begin{array}{l}\text { No. } . . \\
\text { Per cent. }\end{array}$ & $\begin{array}{c}61 \\
40 \cdot 6\end{array}$ & $\begin{array}{c}43 \\
28 \cdot 7\end{array}$ & $\begin{array}{c}16 \\
10 \cdot 7\end{array}$ & $\begin{array}{c}7 \\
4 \cdot 7\end{array}$ & $\begin{array}{l}18 \\
12 \cdot 0\end{array}$ & $3 \cdot 3$ \\
\hline
\end{tabular}

TABLE I

RESPONSE TO TREATMENT

\begin{tabular}{|c|c|c|c|c|c|c|c|c|c|}
\hline \multirow{2}{*}{$\begin{array}{c}\text { Period of Observation } \\
(w \mathrm{ks})\end{array}$} & \multicolumn{3}{|c|}{ DMCT 3-day Schedule } & \multicolumn{3}{|c|}{ DMCT 6-day Schedule } & \multicolumn{3}{|c|}{ Achromycin V 4-day Schedule } \\
\hline & $\begin{array}{r}\text { No. of } \\
\text { Cases }\end{array}$ & Satisfactory & Failed & $\begin{array}{l}\text { No. of } \\
\text { Cases }\end{array}$ & Satisfactory & Failed & $\begin{array}{l}\text { No. of } \\
\text { Cases }\end{array}$ & Satisfactory & Failed \\
\hline $\begin{array}{c}\text { No Follow-up } \\
1 \\
2 \\
3 \\
4 \\
6 \\
8\end{array}$ & $\begin{array}{r}7 \\
43 \\
33 \\
24 \\
17 \\
10 \\
8\end{array}$ & $\begin{array}{r}\overline{39} \\
32 \\
24 \\
17 \\
9 \\
8\end{array}$ & $\begin{array}{r}-4 \\
1 \\
- \\
1\end{array}$ & $\begin{array}{r}5 \\
45 \\
37 \\
28 \\
20 \\
11 \\
8\end{array}$ & $\begin{array}{r}\overline{42} \\
35 \\
26 \\
20 \\
11 \\
8\end{array}$ & $\begin{array}{l}\overline{3} \\
2 \\
2 \\
- \\
-\end{array}$ & $\begin{array}{l}5 \\
45 \\
37 \\
25 \\
19 \\
15 \\
12\end{array}$ & $\begin{array}{l}\overline{41} \\
35 \\
22 \\
18 \\
15 \\
12\end{array}$ & $\begin{array}{l}-4 \\
2 \\
3 \\
1 \\
-\end{array}$ \\
\hline
\end{tabular}

TABLE II

RELATIONSHIP OF PRESENT TREATMENT FAILURES TO PAST ATTACKS OF NON-GONOCOCCAL URETHRITIS AND ITS RESPONSE TO TREATMENT

\begin{tabular}{|c|c|c|c|c|c|c|c|c|c|}
\hline \multicolumn{7}{|c|}{ Result of Present Treatment } & \multirow{2}{*}{$\begin{array}{r}\text { No. of Cases } \\
6 \\
7 \\
10\end{array}$} & \multirow{2}{*}{$\begin{array}{c}\begin{array}{c}\text { Past Attacks of NGU } \\
\text { (No. of Cases) }\end{array} \\
4 \\
5 \\
4\end{array}$} & \multirow{2}{*}{$\begin{array}{c}\begin{array}{c}\text { Failure to Respond } \\
\text { to Earlier Treatment }\end{array} \\
2 \\
3 \\
2\end{array}$} \\
\hline Failed .. & . & $\ldots$ & $\begin{array}{l}\text { DMCT 3-day Schedule } \\
\text { DMCT 6-day Schedule } \\
\text { Achromycin }\end{array}$ & $\begin{array}{l}\cdots \\
\cdots \\
\cdots\end{array}$ & $\begin{array}{l}\cdots \\
\cdots\end{array}$ & $\begin{array}{l}\cdots \\
\cdots \\
\cdots\end{array}$ & & & \\
\hline Cleared & $\ldots$ & . & $\begin{array}{l}\text { DMCT 3-day Schedule } \\
\text { DMCT 6-day Schedule } \\
\text { Achromycin }\end{array}$ & $\begin{array}{l}\cdots \\
\cdots \\
\cdots\end{array}$ & $\begin{array}{l}\cdots \\
\cdots \\
\cdots\end{array}$ & $\begin{array}{l}\cdots \\
\cdots \\
\cdots\end{array}$ & $\begin{array}{l}37 \\
38 \\
35\end{array}$ & $\begin{array}{r}10 \\
12 \\
7\end{array}$ & $\begin{array}{l}2 \\
3 \\
2\end{array}$ \\
\hline Results n & Known & $\ldots$ & $\begin{array}{l}\text { DMCT 3-day Schedule } \\
\text { DMCT 6-day Schedule } \\
\text { Achromycin }\end{array}$ & $\begin{array}{l}\cdots \\
\cdots \\
\cdots\end{array}$ & $\begin{array}{l}\cdots \\
\cdots \\
\cdots\end{array}$ & $\begin{array}{l}\cdots \\
\cdots \\
\cdots\end{array}$ & $\begin{array}{l}7 \\
5 \\
5\end{array}$ & $\begin{array}{l}2 \\
2 \\
1\end{array}$ & $\overline{1}$ \\
\hline
\end{tabular}


Side-effects of treatment were few and mild (Table IV).

TABLE IV

SIDE-EFFECTS OF TREATMENT

\begin{tabular}{|c|c|c|c|c|}
\hline \multirow{2}{*}{ Treatment } & \multirow{2}{*}{$\begin{array}{c}\text { Number } \\
\text { of } \\
\text { Patients } \\
\text { Observed }\end{array}$} & \multicolumn{3}{|c|}{ Side-effects } \\
\hline & & Diarrhoea & $\underset{\text { Irritation }}{\text { Anal }}$ & Nausea \\
\hline $\begin{array}{l}\text { DMCT 3-day Schedule } \\
\text { DMCT 6-day Schedule } \\
\text { Achromycin V }\end{array}$ & $\begin{array}{l}43 \\
45 \\
45\end{array}$ & $\begin{array}{l}1 \\
1 \\
2\end{array}$ & $\frac{1}{-}$ & $\overline{1}$ \\
\hline
\end{tabular}

\section{Discussion}

It has been shown that early "cure" of NGU after a placebo or with no treatment at all can be expected in 20-25 per cent. of cases (Doyle and others, 1957; Willcox, 1957; Leach, 1959; Csonka, 1959) and, as it is generally accepted that administration of the broad-spectrum antibiotics is followed by an early response in over 70 per cent. of patients (Harkness, 1953; Mayne, 1957; Willcox, 1957; Morton and Read, 1957), it was possible to dispense with untreated controls in this series.

In the absence of bacteriological proof, there is no certainty that the antibiotics used at present actually cure NGU; they are, however, of great help in cutting short the attack in the majority of patients. This prompt symptomatic response is a good practical indicator of the efficacy of the drug used. In this respect Achromycin and Ledermycin (in both dosage schemes) were satisfactory when compared with other antibiotics in similar trials (Willcox, 1957; Jelinek, 1957; Fowler, 1958; Csonka, 1959).

There appeared to be no advantage in prolonging the administration of Ledermycin beyond 3 days; thus the 3-day course of Ledermycin was the simplest and cheapest treatment of the three tried. Several patients who received Ledermycin and who had had experience of the older antibiotic treatment for NGU which had to be taken at 6-hrly intervals throughout the day, commented favourably on being able to dispense with the drug during working hours, a cause of embarrassment in the past.

If one analyses the treatment failures, certain features were found to be common in all three treatment groups; thus 56.5 per cent. of patients who failed to respond to the present treatment had had previous attacks of NGU, and 53.8 per cent. of these had failed on a variety of antibiotics. In the group of patients who showed prompt response in this series, only $26 \cdot 3$ per cent. had a history of past NGU, and of these only $24 \cdot 1$ per cent. were considered to be early treatment failures. It is, therefore, possible that treatment response to broad-spectrum antibiotics may be useful in separating NGU into two main types of different aetiology. After clinical and microscopical examination it was impossible to forecast which patient would do well and which would fail on treatment. In patients who did not respond to antibiotic treatment either in the past or at present, the usual course of the urethritis was protracted over several months with gradual spontaneous improvement.

The side-effects of the drugs used in this trial were rare and did not necessitate the withdrawal of the antibiotics.

\section{Summary}

Achromycin and Ledermycin in two dosage schemes were given to patients suffering from NGU and the immediate clinical response was noted. There was no significant difference between the three treatment groups, and the early favourable response in approximately 90 per cent. of patients compares well with the response to other antibiotics in similar circumstances.

The practical advantage lies with the 3-day course of Ledermycin because of its shortness and simplicity of administration and the saving in cost compared with the other treatments.

The patients who failed to respond to treatment in any group in the present series had a higher incidence of treatment failures with a variety of antibiotics in past attacks than the patients who responded to treatment. It is suggested that the type of response to broad-spectrum antibiotics in NGU may be used to separate it into two types of different aetiology.

We wish to thank Dr. F. J. G. Jefferiss and Dr. R. R. Willcox for their help and for permission to use the cases under their care, and Mr. Ambrose King for his encouragement and help in the preparation of this paper. The work of one of us (G.W.C.) was supported by a U.S. Public Health Service Grant under the aegis of the Medical Research Council Working Party on NonSpecific Urethritis.

\section{REFERENCES}

Csonka, G. W. (1959). Brit. J. vener. Dis., 35, 262.

Doyle, J. O., Gill, A. J., and Laird, S. M. (1957). Ibid., 33, 100.

Editorial. Brit. med.J. (1959). 1, 287.

Finland, M., and Garrod, L. P. (1960). Ibid., 2, 959.

Fowler, W. (1958). Brit. J. vener. Dis., 34, 107.

Harkness, A. H. (1953). Ibid., 29, 134.

Jelinek, G. (1957). Ibid., 33, 156.

Kunin, C. M., and Finland, M. (1958). New Engl.J. Med., 259, 999.

Leach, W. (1959). Brit. J. vener. Dis., 35, 223. 
Mayne, G. O. (1957). Ibid., 33, 244.

McCormick, J. R. D., Sjólander, N. O., Hirsch, U., Jensen, E. R., and Doerschuk, A. P. (1957). J. Amer. chem. Soc., 79, 4561.

Morton, R. S., and Read, L. (1957). Brit. J. vener. Dis., 33, 223.

Vineyard, J. P., Hogan, J., and Sanford, J. P. (1960). "Ántibiotics Annual 1959-60", p. 401.

Willcox, R. R. (1957). Brit. J. vener. Dis., 33, 52.

L'urétrite non-gonococcique traitée par la déméthylchlortétracycline ("'Ledermycine")

\section{RÉSUMÉ}

On donna de l'achromycine et de la "Ledermycine" à certains malades atteints d'urétrite non-gonococcique selon deux plans posologiques. Il n'y avait aucune différence significative entre les réactions de trois groupes de malades étudiés. La réponse rapide et favorable obtenue dans à peu près $90 \%$ des cas est supérieure à celle observée avec les autres antibiotiques dans des circonstances semblables.

Le plan selon lequel la "Ledermycine" est donnée pendant 3 jours est non seulement la méthode la plus rapide et la plus simple mais aussi la moins coûteuse.

Les malades qui ne répondirent à aucune posologie avaient déjà manqué de répondre aux autres antibiotiques plus souvent que les autres cas.

On avance la théorie que la réponse de l'urétrite nongonococcique aux antibiotiques à large spectre permet de distinguer deux types étiologiques de cette condition. 